\title{
REVIEW OF THE CRYOGENIC MACHINING IN TURNING AND MILLING PROCESS
}

\author{
V.BALAJI ${ }^{1}$, S. Ravi ${ }^{2}$, P.Naveen Chandran ${ }^{3}$, K.M.Damodaran ${ }^{4}$ \\ ${ }^{1}$ Research scholar, Department of Mechanical Engineering, Bharath Institute of Higher Education And Research \\ ( BIHER ), Chennai, India. \\ ${ }^{2}$ Professor, Department of Mechanical Engineering, Sriram College of Engineering, Chennai, India. \\ ${ }^{3}$ Professor, Department of Automobile Engineering, Bharath Institute of Higher Education And Research \\ ( BIHER ), Chennai, India.
}

${ }^{4}$ Dean \& Professor, Department of mechanical Engineering, Pallavan College of Engineering,Kanchipuram,India.

\begin{abstract}
Cryogenic Coolents are used in conventional machining in material removing process can increase tool life, better surface finish, dimensional accuracy, and reduce the cutting temp. Main objectives of this paper is to understand the cryogenic machining operations. Various research scholar has done the experimental investigation on the cryogenic coolants in different materials in turning and milling Process. At the end of the review obsrved that cryogenic coolant is most favourable methods for material cutting operations in various aspects for future research is proposed.
\end{abstract}

Key Words: Cryogenic coolents and Machining, Literature Review, cryogenic $\mathrm{LN}_{2}$ Setup, cryogenic $\mathrm{CO}_{2}$ Setup,

\section{INTRODUCTION}

Previous Research Scholar have proved that the most of the energy consumed in machining operation is converted to heat.Many problems that occur in machining are due to heat generated and the high temperature caused by it.so proper selection of cutting fluid is particularly important, because it could affect the tool life, cutting forces, power consumption, machining accuracy, surface finish etc.,

It is very important to apply the cutting fluids to reduce the friction, and remove the heat as early as possible. There are different types of machining environments, They are;

1. Dry machining 2. Flood/Wet cooling 3. Minimal Quantities Lubricant 4. High pressure cooling 5. Chilled air cooling

\subsection{Dry Machining}

Dry cutting is where the coolant is not used for the metal cutting processes The advantages of dry machining include non-pollution of the atmosphere (or water) no residue on the swarf, which will be reflected in reduced disposal and cleaning costs; no danger to health; no injuries to the skin and allergy free.so dry machining is always the best way to sustainability.

\subsection{Flood/Wet Cooling}

It provides the machining operation with a good level of lubrication, cooling and chip removal. Generally, soluble oil is used in the cutting zone by flooding. The functions of cutting fluids are, 1 . Increased tool life 2 . Improved surface finish 3. Improved tolerance 4. Reduction in the cutting force 5 . Reduction in the vibration

\subsection{Minimal Quantities Lubricant(MQL)}

Minimum quantity of lubrication consists of a mixture of compressed air and oil droplets to the chip - tool interface The advantages of MQL significantly improve the tool life and surface finish compared to the conventional flood coolant and dry machining

\subsection{High pressure cooling}

High pressure cooling involves the use of a high pressure jet of soluble oil in the cutting zone

\subsection{Chilled Air Cooling}

In the cold compressed air environment, a air gun with a nozzle is used to direct cold air generated by the air gun to the tool chip interface. With the applications of chilled air cooling during machining, the tool life and surface finish are improved

\section{CRYOGENIC COLLENTS AND CRYOGENIC}

\section{MACHINING}

The application of cryogenic coolents in machining was carried out in the year 1950s.cryogenic cooling is used for effective and fast removal of heat generated during the cutting operations and is used for almost almost all types of material Cryogenics is the science of very low temperature $100 \mathrm{~K} \quad\left(-173^{\circ} \mathrm{C}\right)$ and absolute zero $(0 \mathrm{~K}$ or $273^{\circ} \mathrm{C}$ ). Cryogenics has been derived from two Greek words, namely 'cryos' and 'genes',since 'cryos' means ice cold and 'genes' means born.today cryogenics deals eith temperatures below $-153^{\circ} \mathrm{C}$ or lower. Various cryogenic coolants such as helium, hydrogen, neon, nitrogen, oxygen, argon, 
krypton, xenon, methene, ethene, propane and crbon dioxide are used but work when refered to cryogenic $\mathrm{CO}_{2}, \mathrm{LN}_{2}$ are used for machining.

Cryogenic machining is a material removal process where the conventional cutting fluids are replaced with cryogenics such as liquid nitrogen and $\mathrm{CO}_{2}$ etc., in this method usaually liquefied gases, is directed into the cutting zone temperature and cool down the tool and/or work piece.The cryogenic medium absorbs the heat from the cutting zone and evaporates into the atmosphere.

\section{LITERATURE REVIEW OF TURNING PROCESS}

The majority of research work can be done on cryogenic machining in turning operations because it is easy to understand the cryogenic machining

Turning is a machining operation where a single-point cutting tool is used to removes material from surface of a rotating cylinderical work piece. The tool is fed lineraly in direction and parallel to the axis of the rotation of the work piece

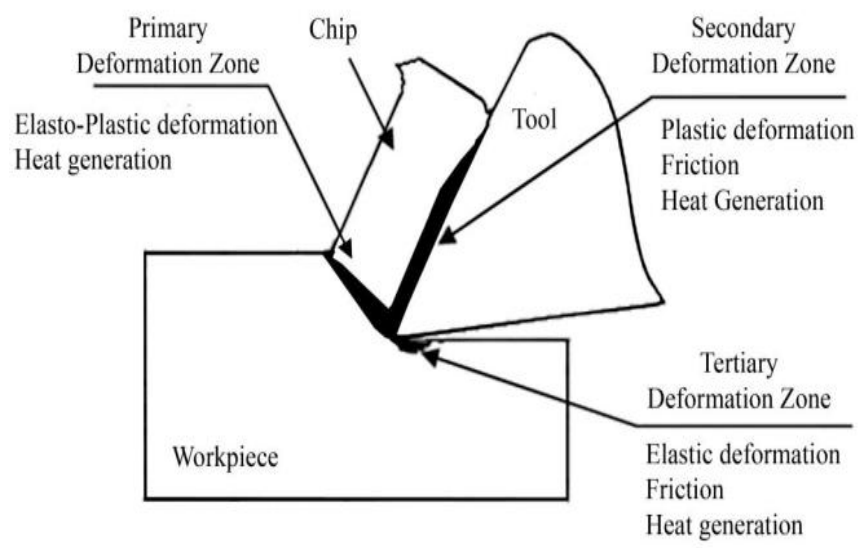

Fig-1 Cutting zone in turning machine

Yields and Muammer Nalbant,2008 is reported that machining in cryogenic cooling is the one of the most favourable methods in metal cutting operations and improvememt in tool life, surface finish,tool wear.

Ahsan Ali Khan and Mirghani (149-154),2008 also reported, that the tool life of the cutting inserts used, improved up to four times with the cryogenic cooling approach. In this work, modified cutting inserts were used for the supply of liquid nitrogen M.Dhananchezian, and M.pradeepkumar,Vol-1,(55-59) 2009 ACEEE investgated in cutting temperature ,cutting force, chip thick ness and shear angle in AISI 1045 Steel and Aluminium 6061-T6 alloy and Proved that temperature was reduced 19-28\% and the cutting force was increased to max $15 \%$ then dry machining of AISI 1045 Steel.In machining Aluminium 6061-T6 alloy , the temperature was reduced to $27-39 \%$ and the cutting force was increased to max $10 \%$

A.A.Khan, M.Y.Ali,and M.M Haque Vol5(171-174) 2010 used work material AISI304 Steel and specialy designed copper nozzle and cutting tool is cotated carbide inserts the results of the investigations showed that most effective way to apply the liquid nitrogen directly applied to machining zone without any interference of the chips tool life is four times increasedcompared to dry machining proces

Umbrello,Pu,Caruso,J.C.Outeiro,(371-376)2011 Experiment were performed under dry and cryogenic conditions using CBN tool inserts using a work material as hardened AISI 52100 Steel,and suggest the cryogenic coolent helps the enhance several aspects of the surface integrity and hard machined components.

Dilip Jerold and pradeep kumar, 2011 measures the cutting temperature,chip thickness,surface roughness,cutting forces using the work material as AISI 1045 Steel and used a cutting tool in multicoated carbide the results says that LN2 proved to be a best alternative cutting fluid in terms of reduced cutting temperature cutting forces and better surface finish.

Dilip Jerold and pradeep kumar,2012 made experimental work and compare performance on cryogenic coolent such as $\mathrm{LN}_{2}$ and $\mathrm{CO}_{2}$ measures the cutting temperature, cutting force, tool wear,surface finish, and chip morphology using the work material as AISI 1045 Steel and used a cutting tool in multicoated carbide inserts the results says that when compared to the use of cryogenic LN2 coolant. Tool wear was found to be less on the application of $\mathrm{CO} 2$ compared to the wet and LN2 machining conditions

Sunil Magadum, (356-1,356-5) 2014 made experiments on lathe using coated carbide tool with cryogenic coolents with flood coolents.test were out at cutting spped of 200 and $250 \mathrm{~m} / \mathrm{min}$ and the feed rate depth of cut was kept constant at $0.2 \mathrm{~mm} / \mathrm{rev}$ and $1.5 \mathrm{~mm}$ respectively.tool wear,tool life and cutting forces were measured the results indicated that cryogenic machining better tool life as compared to conventional flood machining.

\section{LITERATURE REVIEW OF MILLING PROCESS}

Milling is the machining process of using rotatory cutters to remove the material from the surface of a work piece. The milling cutter is a cutting tool with multiple cutting points where the tool is along the rotation of the aixs.

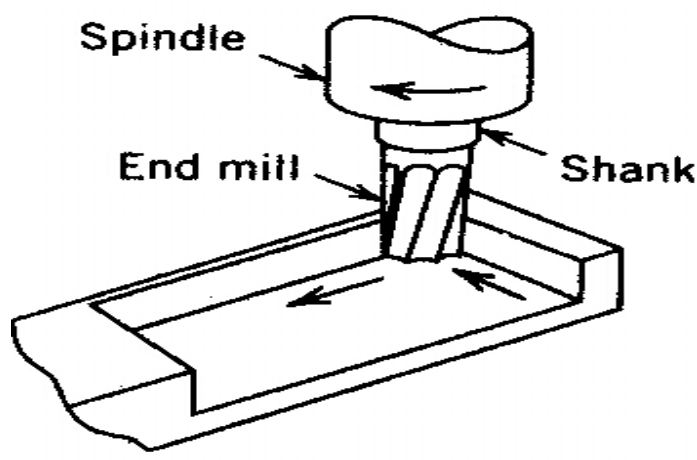

Fig-2 End mill 
Yakup Yildz and Muammer (2011) reported that effect of cryogenic cooling in milling process he takes the work material as AISI 304 Stainless Steel and cryogenic cooling is achived by spraying $\mathrm{LN}_{2}$ to tool , chips and material.and he is measured in cutiing forces in dry and cryogenic cooling conditions. And different cutting speed $(80,120,160, \& 200 \mathrm{~m} / \mathrm{min})$ As a result cryogenic cooling and cutting speed are found to be effective on cutting forces

Ravi and Pradeep kumar (2011) using a work material Hadrdened AISI H13 in slot milling TiAIN PVD carbide tool and he measures the Cutting temperature ,flank wear ,surface roughness ,cutting force in dry and wet machining concluded that by using cryogenic $\mathrm{LN}_{2}$ machining provides better colling and lubrication through substantial reduction in the cutting zone teperature

\section{STUDY OF EXPERIMENTAL CONDITION}

\section{FOR CRYOGENIC MACHINING}

The experimental conditions for cryogenic machining is given bellow in the table
Table-1:Experimental conditions for cryogenic machining

\begin{tabular}{|c|l|c|c|}
\hline $\begin{array}{c}\text { Work piece } \\
\text { material }\end{array}$ & $\begin{array}{l}\text { AISI1045 } \\
\text { steel }\end{array}$ & $\begin{array}{c}\text { AISI 316 } \\
\text { stainless } \\
\text { Steel }\end{array}$ & $\begin{array}{c}\text { Titanium } \\
\text { alloy } \\
\text { (Ti-6Al- } \\
\text { 4V) }\end{array}$ \\
\hline $\begin{array}{c}\text { Cutting tool } \\
\text { insert }\end{array}$ & $\begin{array}{l}\text { Multi-coated } \\
\text { Tungsten } \\
\text { Carbide tool }\end{array}$ & $\begin{array}{c}\text { PVD TiAlN Coated } \\
\text { carbide tool } \\
\text { (CNMG-120404-MP } \\
\text { 431 KC 5010) }\end{array}$ \\
\hline $\begin{array}{c}\text { Cutting } \\
\text { velocity,(m/min) }\end{array}$ & \multicolumn{2}{|c|}{41,94 and 145m/min } \\
\hline $\begin{array}{c}\text { Feed } \\
\text { rate, (mm/rev) }\end{array}$ & $0.051,0.096,0.143$ and $0.191 \mathrm{~mm} / \mathrm{rev}$ \\
\hline $\begin{array}{c}\text { Depth of cut } \\
(\mathrm{mm})\end{array}$ & \multicolumn{2}{|c}{$1 \mathrm{~mm}$} \\
\hline
\end{tabular}

\subsection{Study of Cryogenic setup on $\mathbf{L N}_{2}$}

In this process the cryogenic liquid is stored in cylinderical or spherical shaped tanks including pressure control and vaporizer.in this proces of spraying the cryogenic cooling the pressure in the tank itself forces the coolent to the cutting zone

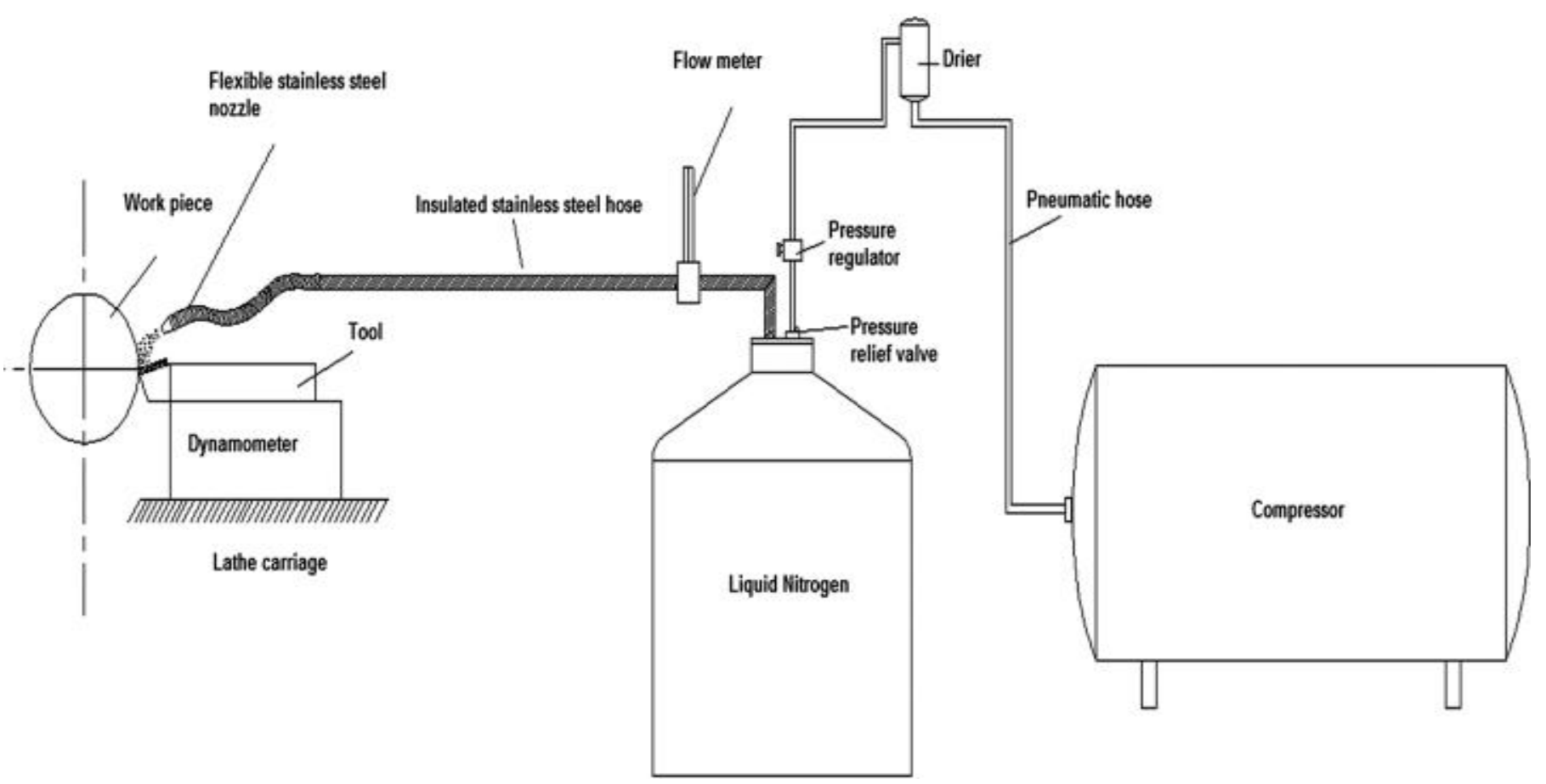

Fig- 3, Cryogenic cooling setup- $\mathrm{LN}_{2}$

\subsection{Study of Cryogenic setup on $\mathrm{CO}_{2}$}

Carbon dioxide cylinder connected with the accessories is shown in Figure 4. 


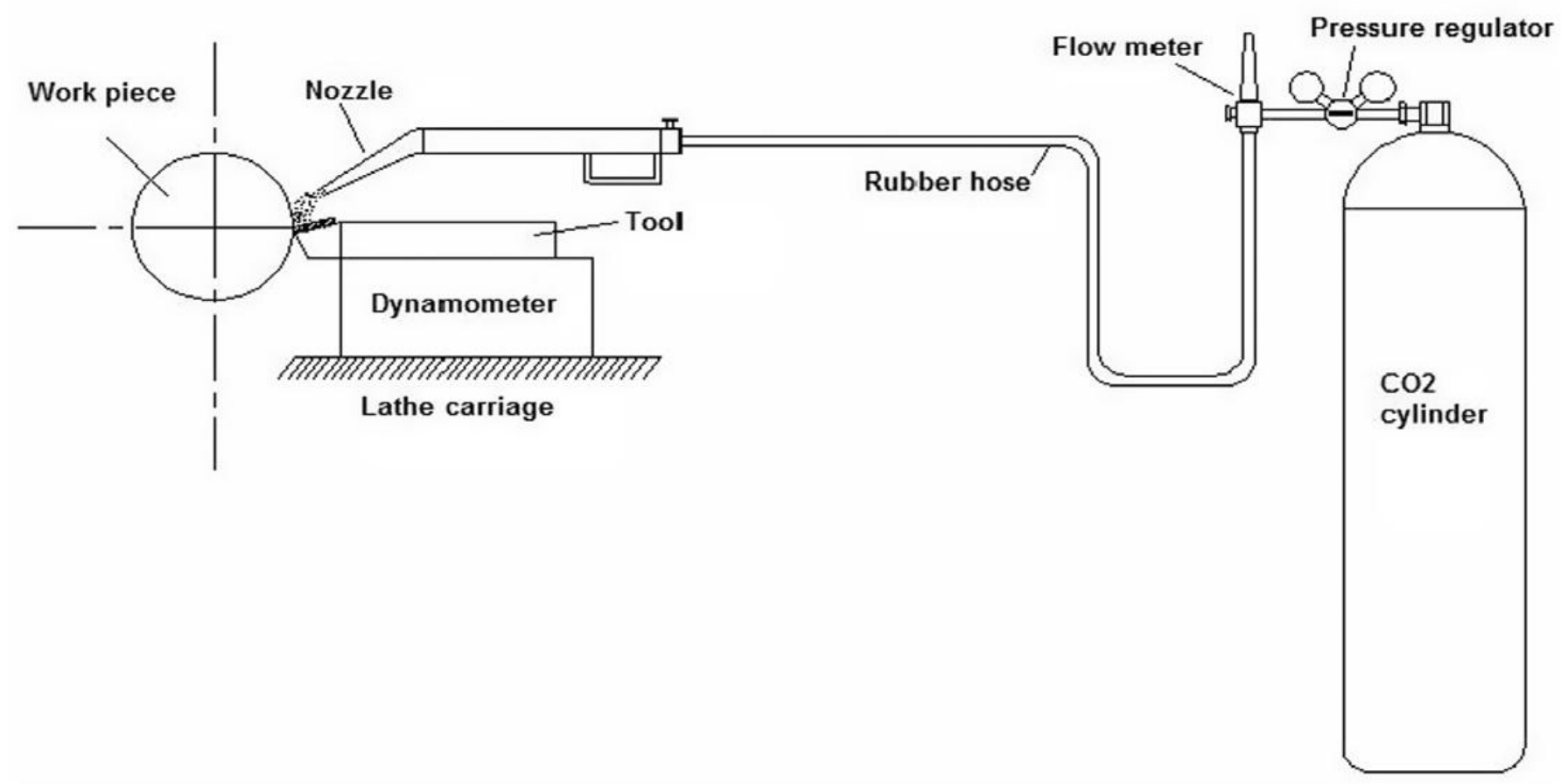

Fig. 4, Cryogenic cooling setup- $\mathrm{CO}_{2}$

In this method $\mathrm{CO}_{2}$ Cylinder is attached with pressure regulator The regulator used for this purpose consists of two dial indicators, one indicating the cylinder pressure and the other indicating the supply pressure Next to the regulator, a carbon dioxide flow meter is attached, to measure the amount of flow of the carbon dioxide coolant. one end of a rubber hose is connected to the outlet of the flow meter, and the other end to a welding torch, whose nozzle tip can be changed as and when required. The welding torch also consists of a valve to control the flow or to stop the flow, whenever the machining process is not carried out. The nozzle tip of the welding torch was pointed towards the cutting zone, to supply carbon dioxide while the machining operation was carried out

\section{SUMMERY}

The review of this paper suggest that cryogenic cooling is a diierent approach and it provides several benifits in machining such as

- Cryogenic cooling is an environment-friendly in such a way that liquid gas is used and it will evaporate into the air

- Cryogenic coolent method has the biggest impact to increasing of tool life, and improvement of surface finish from all cooling approaches

- The cryogenic machining process when $\mathrm{CO}_{2}$ was used as the cutting fluid helped to reduce the cutting forcess abd better chip breakability with reduced chip thickness

\section{REFERENCES}

[1] Yakup Y and Muammer N, A review of cryogenic cooling in machining process, International Journal of Machine Tool and Manufacture, 48 (2008) 947-964.

[2] Dhananchezian M, Pradeep Kumar M. Cryogenic turning of the Ti-6Al-4V alloy with modified cutting tool inserts. Cryogenics 2011;51:34-40.

[3] Jerold, B.D. and M.P. Kumar, 2011. Experimental investigation of turning AISI 1045 steel using cryogenic carbon dioxide as the cutting fluid. Journal of Manufacturing Processes, 13(2): 113-119

[4] Ravi, S. and M.P. Kumar, 2011. Experimental investigations on cryogenic cooling by liquid nitrogen in the end milling of hardened steel. Cryogenics, 51(9): 509-515.

[5] Nalbant, M. and Y. Yildiz, 2011. Effect of cryogenic cooling in milling process of AISI 304 stainless steel.Transactions of Nonferrous Metals Society of China, 21(1): 72-79.

[6] Sunil Magadum,Arun kumar.S,Yoganath V.G,C.K Srinivasa Cryogenic Machining of SS 304 Steel ,AIMTDR 2014 356-1,356-5

[7] Jerold, B.D. and M.P. Kumar,2012 Experimental investigation of carbon-dioxide and liquid nitrogen cryogenic coolents turning of AISI 1045 steel,569-574

[8] A.A.Khan, M.Y.Ali, and M.M Haque, 2010, A New approach of applying cryogenic coolant in Turning AISI 304 Stainless Steel IJMME Vol5(171-174)

[9] Umbrello, Pu,S.Caruso, J.C.Outerio 2011,The effects of cryogenic cooling on surface integrity in Hard machining,371-376

[10] A.A.Khan, Mirghani, 2008, Improving tool life using cryogenic cooling ELSEVIER 149-154 


\section{BIOGRAPHIES}

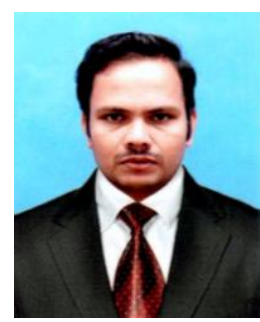

V.BALAJI, Research Scholar from Bharath Institute of Higher Education And Research (BIHER), Chennai, At present he is working with Pallavan college of Engineering, Kanchipuram, Tamilnadu, as a Assistant Professor in Mechanical Engineering Department. 